\title{
INNOVATING CONTENT AND METHODOLOGY OF MANAGEMENT ACCOUNTING EDUCATION IN VIETNAMESE UNIVERSITIES FOR MEETING INTERNATIONAL INTEGRATION
}

\author{
TANDUNG HUYNH, HUYHANH HUYNH, LE THI HAI BINH \\ Industrial University of Ho Chi Minh city, Viet Nam
}

\begin{abstract}
Management accounting is a compulsory subject in the curriculum of accounting at the Vietnamese universities. This subject provides management accounting knowledge and future accounting practising skills to students. In the trend of international integration in economics and education, the role of management accounting is more and more important, it requires accounting graduates to gain professional knowledge about accounting management to meet the needs of domestic and foreign organizations. It poses a challenge for Vietnamese universities in the renewal of contents and teaching methods of management accounting subject, especially when most of the stakeholders suggest increase this subject's credits and contents.

This paper researches the reality of management accounting teaching at the Vietnamese universities and suggests the solutions to innovate this subject's contents and teaching methods. It helps to improve the education quality for accounting students in the trend of international integration.
\end{abstract}

Keywords: Innovation, teaching method, management accounting, international integration.

\section{INTRODUCTION}

Accounting is an indispensable profession in economy. Based on the history of accounting development, accounting existed for a long time and the accounting theory appeared in Venice in 1492 (Frederick D.S. Choi, et al). During the development process, the accounting was divided into two branches: financial accounting and management accounting. In the period 1897 to 1903, the economic integration led to growth and complexity of companies in production, transportation, marketing, finance and human resources. These activities were merged into one or more economic activities and the change of world economic required to cut cost and increase profit. These things had facilitated development of management accounting ( $\mathrm{H}$. Thomas Johnson, 1975). Before the 1950s, management accounting techniques were very simple. They were aimed mainly at determining the production cost. Until the 19th century, the management accounting system (MAS) first appeared in the United States. MAS was applied to both simple and complex accounting methods in this time. Accounts were also used in more detail to determine direct labour costs and general production costs which used to convert raw materials into goods. The use of complex accounting techniques also began in the 19th century (Chandler, D. A. 1977).

Together with the development of economies, accounting was also developing, improving and having more and more requirements. Nowadays, with the trend of globalization and economic integration, accounting plays an increasingly important role in providing information to users in operating and decision making, especially in corporations, multinational companies. In addition, the globalization of education and the movement of labour in accounting and related services among countries in the region also raise the issue of accounting education to meet the requirements of society and compete with other countries in the region. According to Martin 2006, management accounting went through 5 stages of change and development as follows:

Table 1: Summary of development stages of management accounting

\begin{tabular}{|c|c|l|}
\hline Stage & Time & \multicolumn{1}{c|}{ Content } \\
\hline 1 & $1812-1920$ & Emphasize the operation cost, the effectiveness of the production process \\
\hline 2 & $1920-1950$ & Focus on cost determination and financial control \\
\hline 3 & $1951-1980 \mathrm{~s}$ & Focus on information provision for planning and management control \\
\hline 4 & $1980 \mathrm{~s}$ & $\begin{array}{l}\text { Focus on reducing waste, teamwork, Activity Based Costing (ABC), target } \\
\text { costing, quality, investment and product life cycle management. }\end{array}$ \\
\hline 5 & $1990 \mathrm{~s}$ & $\begin{array}{l}\text { Focus on customer value creation, strategy, balanced scorecard (BSC), economic } \\
\text { value added (EVA) and other related concepts. }\end{array}$ \\
\hline
\end{tabular}


Beside the development stages according to Martin 2006, there are other research studied about the development of management accounting, one of them is strategic management accounting (SMA). Strategic Management Accounting was first coined by Simmonds (1981), who defined it as "the provision and analysis of information about a business and its competitors for use in developing and monitoring the business strategy". The role of SMA is supporting the financial needs of management in their task of directing and controlling the business in the best interests of its owners and the other relevant stakeholders. Keith Ward 1992 addresses strategic management accounting as a continuous process of analysis, planning and control.

Currently, in Vietnam there are more than 90 public and non-public universities educating accounting in which management accounting is a compulsory specialized subject in the training programmes. In the bachelor's degree curriculum of these universities, this subject is divided into several modules, from two to three modules, each module has two or three credits. Depending on whether the academic orientation of each school is academic or applicable, this subject is either theoretical or integrated training, both theory and practice. In fact, in many accounting training institutions, the content of management accounting is mainly compiled based on the theory formed for long time and most of them are designed into theoretical modules, little knowledge about practice. The content of this subject mainly presents the methods, the techniques and the reports of traditional management accounting, does not research and teach the theory and methods of modern management accounting. In the process of international economic integration, many universities of the country in the world have studied and applied the theories, contents and techniques of modern management accounting to teach students such as: Activity Based Costing method, target costing method, Balanced Score Card method, and research of integration of many single technical management accounting methods into new method, example $\mathrm{ABC}$ integrated with EVA, ABC integrated with CVP, $\mathrm{ABC}$ combined with $\mathrm{ABM}$, Target Costing combined with $\mathrm{ABC}$.

Regarding the popular teaching methods of this subject in the Vietnamese universities are the traditional method, mainly about lecturing techniques and reports of traditional management accounting, the universities have not yet put into research and taught the theory and method of modern management accounting as mentioned above. This method has not promoted the reasoning and the thinking ability of the learners. Current management accounting requires learners to think and deduce a lot for collecting and practicing the content of management accounting. Therefore, the teaching method of lecturers must also be changed to be suitable with the development innovation requirements of management accounting.

Thus, the current urgent issue for universities with accounting training is to innovate the contents and teaching methods of management accounting to provide quality accounting human resources meet social needs and international integration.

\section{RESEARCH METHODS}

This research applies following methods: qualitative reasearch method. In detail, this study summarizes the results of previous authors' studies, survey enterprises, observation and comparition.

Firstly, the education of management accounting at Vietnamese universities aims to serve intensive human resources in management accounting for businesses. Therefore, the authors study the current status of applying management accounting in Vietnamese enterprises by surveying 469 enterprises in Ho Chi Minh City, Binh Duong and Dong Nai province. The reason authors chose these provinces to conduct the survey is that they have the largest number of enterprises in the southern Vietnam and the variety of businesses and sizes. The survey results help the authors have a comprehensive view of the application of management accounting in these enterprises. We thenceforth can study further to have solutions to improve the quality of human resources for businesses in the field of management accounting.

Secondly, this paper summarizes the current status of teaching management accounting subject in bachelor degree at Vietnamese universities through an overview of previous studies, examines textbooks and syllabuses used to teach management accounting of several Vietnamese universities in Ho Chi Minh City which has education in bachelor accounting in order to understand the contents of teaching this subject at universities. At the same time, the authors carried out the actual observation at the classroom that teach management accounting. Through the observation, the authors can reveal the teaching methods, which lecturers used in this subject. 
Finally, after analysing the results of study, this paper gives Vietnamese universities some suggestions for innovating the content and teaching methods of management accounting in Vietnamese universities today.

\section{THE STATUS OF APPLYING MANAGEMENT ACCOUNTING IN VIETNAMESE ENTERPRISES}

Management accounting is increasingly being widely applied in many countries around the world. However, very few Vietnamese enterprises now apply management accounting in business management. The survey result of 469 Vietnamese enterprises by different location and size is presented in table 2:

Table 2: Number of surveyed enterprises by location and size

\begin{tabular}{|l|c|c|c|c|c|}
\hline \multicolumn{1}{|c|}{ Locality } & Total & Big enterprise & $\%$ & $\begin{array}{c}\text { Small and } \\
\text { medium } \\
\text { enterprise }\end{array}$ & $\%$ \\
\hline Ho Chi Minh city & 195 & 86 & 44.10 & 109 & 55.90 \\
\hline Binh Duong province & 148 & 67 & 45.27 & 81 & 54.73 \\
\hline Dong Nai province & 126 & 57 & 45.24 & 69 & 54.76 \\
\hline Sum & 469 & 210 & 44.78 & 259 & 55.22 \\
\hline
\end{tabular}

The survey result shows that management accounting is integrated in financial accounting, it has not been organized into a system with all its functions and tasks. The details are shown in Table 3 below.

Table 3: Results of surveying the situation of applying management accounting

\begin{tabular}{|l|c|c|c|c|c|c|}
\hline \multicolumn{1}{|c|}{ Content } & $\begin{array}{c}\text { Ho Chi } \\
\text { Minh }\end{array}$ & $\%$ & $\begin{array}{c}\text { Binh } \\
\text { Duong }\end{array}$ & $\%$ & Dong Nai & $\%$ \\
\hline Enterprises apply & 188 & 96.41 & 143 & 96.62 & 118 & 93.65 \\
\hline Enterprises do not apply & 7 & 3.59 & 5 & 3.38 & 8 & 6.35 \\
\hline Combined with financial accounting & 193 & 98.97 & 147 & 99.32 & 126 & 100.00 \\
\hline Organized into a separate system & 2 & 1.03 & 1 & 0.68 & 0 & - \\
\hline
\end{tabular}

Source: Author's survey, $\mathrm{N}=469$

In addition, most companies use traditional management accounting techniques and methods. The level of required accounting management information in these enterprises is only at a very basic level, mainly the information on the calculation of product cost by the traditional method, determining the selling price, make sales plan, purchase of materials and estimates of general production costs, selling expenses, and enterprise management costs. All enterprises surveyed do not use modern methods and techniques of management accounting. The results are shown in Table 4 below.

Table 4: Survey result of applying contents, methods and techniques of management accounting

\begin{tabular}{|l|c|c|}
\hline Content & Application & Non-application \\
\hline $\begin{array}{l}\text { Classification of costs according to variable cost, fixed cost and } \\
\text { mixed cost }\end{array}$ & 32 & 417 \\
\hline Prepare forecasts budget & 186 & 263 \\
\hline Determine the price based on the variable cost & 2 & 447 \\
\hline $\begin{array}{l}\text { Determine the selling price based on the total cost (do not classify } \\
\text { into variable cost and fixed cost) }\end{array}$ & 218 & 231 \\
\hline Analysis of cost fluctuations & 185 & 264 \\
\hline Analysis relationship of Cost - Volume - Profit & 32 & 417 \\
\hline $\begin{array}{l}\text { Calculating cost by traditional method (simple, step by step, } \\
\text { according to production process) }\end{array}$ & 449 & 0 \\
\hline Activity based costing (ABC) & 0 & 449 \\
\hline Target costing & 0 & 449 \\
\hline Life cycle costing & 0 & 449 \\
\hline Balanced Score Card & 0 & 449 \\
\hline Activity-based management & 0 & 449 \\
\hline Economic value added (EVA) & 0 & 449 \\
\hline
\end{tabular}


Through survey results, enterprises have not yet applied management accounting or only applied a part of the contents of management accounting, mainly focus on the following reasons: financial resources, human resources, leaders have not seen the roles and the importance of management accounting, have not believed in the management accounting information provided. Among the above reasons, the main reason that the enterprises feedbacked lack of the quality human resources to apply management accounting. So that the research team pay attention to focus on the accounting human resource educated in Vietnamese universities. Human resources work in management accounting are provided by accounting training institutions including universities. Thus, what is the current status of management accounting education at Vietnamese universities? Is there a supply of human resources that meet the requirements of the business? Is it on par with other countries in the region?

\section{THE STATUS OF TEACHING MANAGEMENT ACCOUNTING IN VIETNAMESE UNIVERSITIES}

\section{About contents of management accounting subject}

According to department of accounting and auditing supervisory, Ministry of Finance 2017, the school should implement the guideline that educating what the society needs rather than educating what it has, ending the training method of sentence quote, do not let accounting students become robots because they only memorize the theory but do not know how to apply theory to practice. Vietnam has achieved international economic integration, but the current contents and methods of the management accounting education in Vietnamese universities do not meet the requirements of international integration. Most of universities currently compose the contents of management accounting subject based on several foreign books and definitions in the accounting law issued by the Ministry of Finance in 2005. The contents of this subject usually introduce concepts, methods and basic techniques of management accounting. However, the current contents of management accounting lack updating modern management accounting knowledge. That mean the graduates from universities lack a lot of modern management accounting methods and techniques.

According to many authors, the current accounting education do purely in a way that shows how to rigorously do not let people know why to do so. Learners who have only been taught about how to do will lose their creativity. Accounting education in general and management accounting education in Vietnam universities still exist many shortcomings, the expected gap of employers and graduates is quite large, the number of graduates who do not work in the right specialized job or have no jobs tend to increase. The subject content is also based on pure theory, it has few practical hours and self-study hours of students (Dang Duc Son, 2013, Department of Accounting and Auditing Regime, Ministry of Finance 2017).

The authors examined the textbooks and syllabuses used to teach the management accounting of several Vietnamese universities in Ho Chi Minh City which specialized training in accounting. The examined results are shown in the following table:

Table 5: The examined results of management accounting contents used to teach at universities
General issues of management accounting
Costs and cost classification
Cost management accounting and costing methods
The relationship among cost - volume - profit
Determine selling price of product
Management accounting for business decision making
Prepare forecasts budget
Analysis of cost fluctuations for decision making
Performance measurement in decentralized organizations

Source: Authors summarize from universities

The big problems that exist in the accounting education system in Vietnam are that there is too much emphasis on financial accounting, and accounting education is still largely based on prescribed accounting systems. When developing an accounting course curriculum, education institutions must follow the framework of Ministry of Education and Training (Tandung Huynh et al., 2014). The curriculum of management accounting in Vietnam universities is currently in the third stage in the development of management accounting from 1951 - 1980's. It focuses on information provision for planning and management control. Modern management accounting contents have not been adopted to 
teach in Vietnamese universities. There are just some few universities in Ho Chi Minh City, such as University of Economics Ho Chi Minh City, Industrial University Ho Chi Minh City, which introduce management accounting books in English to students, they can use those books to research alongside the Vietnam management accounting books. The contents of management accounting are also limited to some basic contents. In spite of the requirements of economic integration, accounting integration, the contents of management accounting subject taught at Vietnamese universities are still inadequate and out of date. To achieve the goal of integration and application of management accounting in practice, the universities need to compile the contents of management accounting subject to suit the reality and requirements of enterprises, provide graduates meet the social needs of accounting human resources.

\section{About the teaching method of management accounting subject}

Teaching methods of management accounting subject which are often applied by lecturers are lecturing and doing exercises. The lecturers mainly present the main contents such as principles, methods of recording, measuring business operations and presenting information on management accounting reports. Traditional teaching methods still play a key role in teaching management accounting. Therefore, Truong Thanh Hang, Nguyen La Soa 2017, Nguyen Thi Mai Huong 2017 said the previous teaching method of "reading, writing and homework" is now replaced by the formula "lecturing, listening and doing exercises". This approach seems to have renewed the teaching method but does not guarantee encourage learners to work and does not guarantee knowledge for high-level learners, learners only learn what lecturers presented.

Management accounting is not only concepts, definition and doing homework as a framework, but also is a scientific subject. So that, the training of accountants should firstly provide them thinking method, method of solving problems rather than making them memorize records and reports. According to many studies in the world, students learn more today, acquire more and more successful when they approach to active learning methods instead of traditional and passive learning methods (Bonwell and Eison, 1991; Meyers and John, 1993; Raux, 2004, 2009). Active learning provides opportunities for students to interpret, listen, demonstrate their ability to read, write and reflect the content, ideas, problems, concepts of a subject (Meyers and Jones, 1993). According to Braun and Sellers (2012). The important role of lecturers does not only provide students with accounting knowledge and skills, but also teach students the skills of communication, professional ethic and ability to behave appropriately and professionally in each situation. According to the Education Law, the requirements of university-level training methods are "to foster the sense of self-discipline in learning and self-study capacity, self-research, developing creative thinking, practical skills and facilitating learners to participate in research, experiment, application".

Therefore, Tran Hong Van, Duong Hoang Ngoc Khue, 2017 said that the teaching method needs to adjust to approach the principles and methods, also combine situations for students to understand about the depth of management accounting and handle good management accounting issues in practice in Vietnam. The authors observed at several universities in Ho Chi Minh City. In the classroom, lecturers also frequently discussed with students during the lecture process, for example, illustrate and assign exercises in class, assign homework, require students to perform situations or exercises in groups or individually on applying the theories, methods and techniques of the management accounting. However, the frequency of communication between lecturers and students is still low and there is no mechanism for checking and controlling assignments for students.

Through the observations together with previous authors' studies, it can be concluded that most universities in Vietnam still use traditional methods in teaching management accounting. Some lecturers also change, improve teaching methods but generally have not escaped the nature of traditional teaching methods.

\section{SOLUTION OF INNOVATING CONTENTS AND TEACHING METHODS OF MANAGEMENT ACCOUNTING SUBJECT}

\section{Innovating contents of management accounting subject}

Management accounting is a subject that equips accounting learner professional knowledge and skills to ensure learners can do management accounting in domestic and foreign corporations. During the economic integration period, the contents of management accounting subject require meeting the requirements of providing detailed economic information, financial information and non-financial 
information for user to make decisions. Therefore, the contents of this subject need to be compiled and taught in universities according to the following orientations:

Firstly, universities should supplement the content of management accounting according to the modern theory approach to meet the current economic integration objectives. The content includes not only cost control and planning but also modern technical tools to assess business performance. Thereby, it will change the students' perception of the management accounting role to work in the future. They play the role not only of accountants in providing financial information but also of consultants in participating in the decision-making process, rather than participating in the process of developing and implementing business strategies.

Secondly, the core issue is that students understand the nature of economic information so that they can apply the knowledge of management accounting to reasoning, analysing, presenting reports in many ways to well serve user needs. Therefore, it is necessary to put many practical situations into the content of the subject in combination with the seminars from accounting associations CIMA, ACCA, CFA to guide and explain clearly the contents to be taught. The lecturer should change teaching method which help the students to learn from "remember" to "understand" and "apply".

Thirdly, the content compiled in the management accounting subject should be presented bilingual for students, thereby it helps to improve their ability to use specialized terms in English, proceed to selfreading and apply the contents of management accounting whenever there are new changes or updates.

Fourthly, Vietnamese universities should strengthen the amount of training for the accounting management module, most Vietnamese universities currently only spend a little time for this module, only four to five credits and divided into two modules. With few credits, the contents of this subject lead to inadequate teaching time of modern management accounting content. The proportion of management accounting is only about $30 \%$ of the financial accounting's training time in comparison. In order to meet the teaching duration of management accounting subject, it is necessary to enhance the teaching time of management accounting subject up to 8 to 9 credits to train the contents of modern management accounting to students and to be suitable with the curriculum of universities in the area that have tested AUN.

Fifthly, Vietnamese universities should integrate both theory and practice in each module of this subject. Management accounting subject can be divided into 3 modules, each module has 3 credits including 2 theoretical credits and 1 practical credit. Practical contents are situations of actual management accounting that can be instructed in theory class or simulated practice room to simulate management accounting work in a specific organization. It helps students to act as true management accountants in practical organizations. In addition, the practical contents in the subject focus on not only professional skills but also reporting skills, writing skills, skills in using body language, issues related to professional ethics, reasonable behaviour, professional working style in each real situation. The practice not only conduct by paper-based situations, but also by the computer-based exercises. It is useful for students to create management accounting reports that are the same as those used by businesses. Moreover, the management accounting practice also needs to incorporate statistical analysis tools based on statistical software to equip students with analytical techniques and skills to handle large data sets.

\section{Innovating the teaching methods of management accounting subject}

The renewal of the content of management accounting subject must be done in parallel with innovating teaching methods to help students achieve the learning outcomes of this subject easily. Converting from traditional teaching methods to active methods, learner centered teaching, promoting students' proactive must be applied thoroughly to direct students to apply the modern management contents, improve occupational judgement skills to solve real problems. The teaching methods must achieve the main objectives that students not only understand the management accounting theory and apply it to do exercise but also apply management accounting to specific situations in practice.

Therefore, the authors propose several active teaching methods which will be suitable to teaching management accounting subjects:

- Interactive lecturing

Lecturing is a traditional teaching method; however, no modern teaching method can ignore this method. Lecturers should limit speaking throughout the class because it is a one-way teaching, a passive 
teaching method. It does not give students the opportunity to interact with teachers, so that it is not suitable for teaching contents of management accounting. When teaching management accounting, the interpretation of concepts, methods and techniques should be done in an interactive, problematic way for students to brainstorm and be attracted in the problem-solving process with lecturers. This method helps students have more opportunities to interchange with lecturers to understand the nature of management accounting.

- Teaching based on project

Management accounting does not have rules, theoretical frameworks, specific guidelines like financial accounting. Therefore, it is essential and innovative to teach students to identify economic issues to decide on handling, analysing and making decisions in management accounting. To promote the effectiveness of this method, lecturers should organize students to work in groups and everyone will work with the team to find out the best way to solve problems. Thereby, students can find out core knowledge of management accounting, apply them to exercises and practical situations. They can develop the ability to think independently, ability to detect and solve problems.

- Learners centered teaching

This method is also very suitable for management accounting education. Lecturers are instructors, students are the centre of learning. Students actively state their opinions, so that the teaching process will be closer to the needs of students in understanding and applying knowledge, methods and techniques of management accounting. Lecturers should combine this method with other teaching methods such as roleplaying, brainstorming, teamwork. It will help students actively comprehend management accounting knowledge under the guidance of lecturers. Each theory, each method, each technique needs to be used to handle real problems. And students can actively select, discuss and find out the nature of those problem. Teachers should only give orientation and guidance to help students effectively absorb the content to be communicated.

- Teaching by situation

As mentioned in the above methods, students must apply the contents of management accounting in specific situations as well as apply them to practice. Therefore, the method of teaching by the situation is very suitable in the current management accounting education. Lecturers need to include in their lecture's real management accounting situations, so that students can participate in solving these situations which helps students to access professional practices in the classroom. Because of the real nature of the situations, the students are proactive, creative, and interested in the lesson and thus approach and apply effective management accounting.

Whether traditional or modern teaching methods need to be adjusted towards the principles, theories and nature of management accounting, also combining with methods of solving real situations at Vietnamese enterprises, from there students can know about the theoretical and practical contents of management accounting. Besides that, it is necessary to corporate with professional accountants and auditors working at domestic and foreign companies and corporations with many years of working experience to exchange practical issues and answer questions many accounting problems, practical management accounting situation for students.

In addition, Vietnamese universities which specialized in accounting education should also pay attention to investing in modern teaching and learning facilities for students such as e-learning, stimulation room... and establishing accounting clubs and professional accountant organizations to help student be able selfstudy and exchange practical learning.

\section{CONCLUSION}

Innovating the contents and teaching methods of management accounting subject is one of the concern issues in Vietnamese universities having accounting education. In order to improve the quality of education, the contents of management accounting subject needs to be updated and renewed according to the approach of modern management accounting. In addition, active teaching methods such as interactive lecturing, problem-based learning, learner centered teaching, teaching by situation, etc also need to be exploited and applied widely.

\section{ACKNOWLEDGEMENT}


We would like to thank our colleagues and collaborators. Authors thank to editorial board of Journal of Science and Technology - Industrial University of HCMC, Reviewers, and all previous researchers that our paper cited.

\section{REFERENCES}

Bonwell, C. C. and Eison, J. A., 1991. "Active Learning: Creating excitement in the classroom", ASHEERIC Higher Education Report No. 1, Washington D.C.: The George Washington University, School of Education and Human Development.

Braun, K. W. \& Sellers, R. D., 2012. Using a "Daily Motivational Quiz" to Increase Student Preparation, Attendance, and Participation. Issues in Accounting Education 27(1): 267-279.

Chandler, D. A., 1977. "Visible Hand: The management revolution in American business". Cambridge: Harvard University Press.

Dang Duc Son, 2013. Issues to improve the quality of accounting and auditing personnel in Vietnam. Proceedings of Workshop of Accounting - Auditing in the process of reform and integration, 302-305.

Department of Accounting and Auditing Regime, Ministry of Finance 2017. Develop and perfect the legal framework for financial reporting standards in Vietnam, Scientific Conference, Ho Chi Minh City.

Frederick D. S. Choi , Gary K. Meek, 2010. International Accounting (7th Edition), Pearson, p 5.

H. Thomas Johnson, 1975. Management Accounting in an Early Integrated Industrial: E. I. Dupont de Nemours Powder Company, 1903-1912, Business History Review 49 (2).

Keith Ward, 1992. Strategic Management Accounting, Chartered Institute of Management Accountants, Taylor \& Francis Ltd, United Kingdom.

Meyers, C. and Jones T.B., 1993. Promoting Active Learning: Strategies for the College Classroom, Jossey-Bass Publishers, San Francisco, CA.

Nguyen Thi Mai Huong, 2017. Innovating the programme, improving the quality of specialized training in Accounting and Auditing to meet integration requirements, Scientific workshop, HCMC.

Raux, Donald J., 2004. "Implementing Active Learning in College Accounting Classes", Explorations in Teaching and Learning 16 (1).

Raux, Donald J., 2009. "Teaching an Effective Accounting Class in the 21st Century: Using Active Learning Techniques". European Journal of Management 9(4)

Simmonds, K.,1981. Strategic management accounting. Management Accounting, 59 (4): 26-30.

Tandung Huynh et al, 2014. Suggest solutions for diffusion and implementation of activity-based costing in Vietnam. Asian Economic and Financial Review 4(2):173-182.

Tran Hong Van, Duong Hoang Ngoc Khue, 2017. Integrate IFRS in the Accounting curriculum, Scientific workshop, HCMC.

Truong Thanh Hang, Nguyen La Soa, 2017. Innovating the accounting curriculum, in Vietnamese Universities Should follow the principles or rules, Scientific workshop, HCMC. 


\section{ĐỔI MỚI NỘI DUNG VÀ PHƯƠNG PHÁP ĐÀO TẠO KẾ TOÁN QUẢN TRI TRONG CÁC TRƯờnG ĐẠI HỌC VIỆT NAM NHẦM ĐÁP ÚNG SỰ HộI NHẬP QUỐC TẾ}

Tóm tắt. Kế toán nói chung và kế toán quản trị nói riêng là môn học bắt buộc trong chương trình đào tạo ngành kế toán tại các trường đại học Việt Nam nhằm cung cấp cho sinh viên những kiến thức chuyên sâu trong lĩnh vực kế toán quản trị và những kỹ năng hành nghề kế toán trong tương lai. Trong xu thế hội nhập quốc tế về kinh tế và giáo dục ngày càng sâu rộng, đòi hỏi sinh viên tốt nghiệp ngành kế toán cần đạt được các kiến thức chuyên môn về kế toán để đáp ứng được nhu cầu của các tổ chức trong và ngoài nước. Điều này đặt ra một thách thức cho các trường đại học Việt Nam trong việc đổi mới nội dung và phương pháp giảng dạy môn học kế toán quản trị, nhất là khi đa số các ý khảo sát các bên liên quan trong quá trình làm chương trình đạo tạo chuyên ngành kế toán và kiểm toán đều đề nghị tăng cường nội dung và số tín chỉ giảng dạy cho học phần kế toán quản trị. Trong phạm vi bài viết này, tác giả trình bày thực trạng giảng dạy môn học kế toán quản trị tại các trường đại học Việt Nam hiện nay và đưa ra một số giải pháp đổi mới nội dung và phương pháp giảng dạy môn học này nhằm nâng cao chất lượng đào tạo môn học kế toán quản trị cho sinh viên ngành kế toán trong xu thế hội nhập quốc tế.

Từ khóa. Đổi mới phương pháp giảng dạy, kế toán quản trị, hội nhập quốc tế

Ngày nhận bài: 02/12/2019

Ngày chấp nhận đăng: 25/02/2020 